\title{
Effect on Patients' Outcomes of a Change to Biosimilar Filgrastim Product in Autologous Stem Cell Mobilization
}

\author{
Jennifer Fenna, Micheal Guirguis, Caroline Ibrahim, Neeta Shirvaikar, Irwindeep Sandhu, \\ Sunita Ghosh, and Melissa Jenkins
}

Can J Hosp Pharm. 2021;74(2):122-9

\begin{abstract}
Background: Following addition of a biosimilar filgrastim product to the formulary, sites in the authors' provincial health authority transitioned from using the originator filgrastim to the biosimilar for autologous stem cell mobilization.

Objective: To assess the effect on patient outcomes of a universal change to use of the biosimilar filgrastim in stem cell mobilization.

Methods: This retrospective pre-post study included patients undergoing autologous stem cell mobilization at 2 cancer hospitals in Alberta, Canada, between July 1, 2018, and November 30, 2019. Clinical outcomes were investigated for patients treated with a granulocyte colony-stimulating factor (biosimilar or originator product) for mobilization before stem cell transplant, approximately 6 months before and after the defined date of product change.
\end{abstract}

Results: In total, 102 patients were treated with the originator product and 101 patients with the biosimilar. Effectiveness was similar between the originator and biosimilar products, with $98 \%$ successful harvest of stem cells in all patients treated. Independent $t$ tests showed no statistically significant differences between patients receiving the originator and those receiving the biosimilar in terms of time from mobilization to collection (difference of means -0.9 days, $95 \%$ confidence interval $[\mathrm{Cl}]-2.12$ to 0.32 ), time for neutrophil engraftment (difference of means 0 days, $95 \% \mathrm{Cl}-0.36$ to 0.36 ), time for platelet engraftment (difference of means 1 day, $95 \% \mathrm{Cl}-0.55$ to 2.55 ), average length of stay (difference of means -0.7 day, $95 \% \mathrm{Cl}-2.71$ to 1.31), and CD34+ value (difference of means $-1 \times 10^{6} / \mathrm{kg}$ body weight, $95 \% \mathrm{Cl}-2.11$ to 0.11$)$. A $98 \%$ rate of conversion to use of the biosimilar filgrastim was achieved, with an estimated annual drug-cost saving of $\$ 67500$.

Conclusions: In this pre-post study, changing to the biosimilar product from the originator maintained clinical effectiveness outcomes while decreasing overall drug expenditures. A well-planned change to the biosimilar product, executed in conjunction with clinician consultation and monitoring of effectiveness outcomes, can ensure appropriate patient therapy while significantly improving the uptake of biosimilars and decreasing expenditures for biologic drugs.

Keywords: biosimilar, filgrastim, autologous stem cell transplant

\section{RÉSUMÉ}

Contexte : À la suite de l'ajout d'un produit filgrastim biosimilaire à la liste des médicaments, les sites relevant de l'autorité sanitaire provinciale des auteurs sont passés de l'utilisation du filgrastim princeps à la version générique pour la mobilisation des cellules souches autologues.

Objectif : Évaluer l'effet sur les résultats des patients d'un changement généralisé visant à utiliser le filgrastim générique pour la mobilisation des cellules souches.

Méthodes : Cette étude rétrospective pré-post comprenait des patients soumis à une mobilisation des cellules souches autologues dans deux hôpitaux de cancérologie en Alberta (Canada) entre le 1er juillet 2018 et le 30 novembre 2019. L'examen des résultats cliniques des patients traités à I'aide d'un facteur stimulant les colonies de granulocytes (G-CSF) (générique ou princeps) pour une mobilisation avant la greffe de cellules souches a eu lieu environ six mois avant et après la date du changement de produit.

Résultats : Au total, 102 patients ont été traités à l'aide du produit princeps et 101 patients à l'aide du générique. Les deux produits présentaient une efficacité similaire, et $98 \%$ de réussite dans la récolte de cellules souches chez tous les patients traités. Des tests $t$ indépendants n'ont montré aucune différence statistique significative entre les patients recevant le princeps et ceux recevant le biosimilaire en termes de temps allant de la mobilisation à la collecte (différence des moyennes $-0,9$ jour, intervalle de confiance [IC] $95 \%-2,12$ à 0,32); temps de la prise de la greffe neutrophile (différence des moyennes 0 jour, IC $95 \%-0,36$ à 0,36); temps de la prise de la greffe des plaquettes (différence des moyennes 1 jour, IC $95 \%-0,55$ à 2,55); durée moyenne du séjour (différence des moyennes -0,7 jour, IC $95 \%$ $-2,71$ à 1,31) et valeur CD34+ (différence des moyennes $-1 \times 10^{6} / \mathrm{kg}$ masse corporelle, IC $95 \%-2,11$ à 0,11). Un taux de conversion de $98 \%$ visant à utiliser le filgrastim générique a été atteint, avec une estimation des économies annuelles sur le coût des médicaments de 67500 \$.

Conclusions : Dans cette étude pré-post, le passage du produit princeps au générique a préservé l'efficacité des résultats cliniques, tout en diminuant les dépenses générales liées au médicament. Un changement bien programmé pour passer au produit générique, mené conjointement avec la consultation d'un clinicien et un contrôle des résultats d'efficacité, peut assurer une thérapie du patient appropriée tout en améliorant grandement la prise de produits génériques et en diminuant les dépenses associées aux médicaments biologiques.

Mots-clés : biosimilaire, générique, filgrastim, greffe de cellule souche autologue 


\section{INTRODUCTION}

Filgrastim is a granulocyte colony-stimulating factor (GCSF) hematopoietic agent ${ }^{1}$ used in stem cell mobilization protocols before autologous stem cell transplant (ASCT) in patients with hematologic malignancies. A biosimilar product for the originator filgrastim product has been available in Canada since 2016. ${ }^{1}$ In the period of 2018 to 2019, following a formulary addition by the Drugs and Therapeutics Committee of the provincial health authority (Alberta Health Services [AHS]), all sites transitioned from using the originator filgrastim to the biosimilar product for most indications, including autologous stem cell mobilization. The aim of the current study was to compare the effectiveness of the 2 products for mobilization, given that comparative data have not been well investigated for this indication in Canada.

Biosimilar drugs demonstrate a high degree of similarity to an already authorized biologic drug, with no expectation of clinically meaningful differences in effectiveness or safety between the biosimilar and the originator product., ${ }^{2,3}$ However, in Canada and other parts of the world, the uptake of biosimilars has not reached its full potential. ${ }^{4,5}$ Previous publications have described barriers to biosimilar uptake. ${ }^{6,7}$ Despite there being no expected difference in effectiveness between a biosimilar and its originator product, prescribers have limited comfort and confidence when biosimilars enter the market. ${ }^{6,8}$ This lack of uptake may be more discernible when products are being prescribed for "at-risk" patient populations, for which there is a lack of data in the studies submitted for approval of the biosimilars. ${ }^{6,8}$ At-risk patient populations are people with the highest potential for serious consequences from a failure of therapy, as well as low tolerance for treatment failure because of the acuity of their condition or previous treatment failures. Our study applied this definition to patients undergoing preparation for stem cell mobilization and ASCT. We aimed to address the data gap and clinical comfort issue related to this indication for a Canadian biosimilar filgrastim product.

At the time of planning for the project, literature was beginning to emerge regarding the use of biosimilar filgrastim products in ASCT. Searches for published studies of autologous stem cell mobilization with biosimilar filgrastim were conducted in the PubMed and ClinicalTrials.gov databases and using the Google search engine. A 2016 meta-analysis by Schmitt and others ${ }^{9}$ included 30 studies (involving a total of 1541 patients who underwent autologous transplant) that used biosimilar filgrastim products (Zarzio ${ }^{\mathrm{TM}}$ or Ratiograstim $^{\mathrm{TM}} /$ Tevagrastim $^{\mathrm{TM}}$ ). The meta-analysis showed no significant differences between the biosimilars and originator product in terms of number of apheresis sessions, CD34+ cell count, and time to recovery of neutrophil count or platelet count after engraftment. ${ }^{9}$ Another review article ${ }^{10}$ included 7 retrospective and prospective studies comparing biosimilar filgrastim with originator filgrastim; the findings of these trials supported effectiveness of the biosimilar in terms of both mobilization and transplant-related outcomes. Several recent studies have investigated the use of biosimilar filgrastim in ASCT, concluding that biosimilar filgrastim is safe to use for stem cell mobilization, with no disparity in clinical effect. ${ }^{7,8,11,12}$

In the literature, Canadian data are notably lacking, except for 1 poster abstract describing the experience at a Saskatchewan cancer centre after a switch to the biosimilar Grastofil ${ }^{\circledR}$ for ASCT. ${ }^{13}$ Marketing surveillance and pharmacovigilance data on adverse effects are monitored and reviewed by the Canadian regulatory body, Health Canada, and have not revealed any unexpected post-authorization signals for biosimilars at this time. ${ }^{14}$ Because biosimilar products are not exact copies of one another, and because there are some important differences in national policies for approval of biosimilars and drug formulary coverage elsewhere in the world, Canadian findings are of value to support jurisdictional decisions. The results of the current health care improvement project will add to the available literature, helping to support clinical practice. Increasing the uptake of biosimilars within organizations can reduce health system drug expenditures and increase patients' access to high-cost medications. ${ }^{7}$

The goal of this study was to confirm the similarity between the biosimilar and originator filgrastim products by comparing clinical outcomes for patients in Alberta who were treated with GCSF for stem cell mobilization before ASCT at the Cross Cancer Institute (CCI) in Edmonton and the Tom Baker Cancer Centre (TBCC) in Calgary, approximately 6 months before and after a defined date of product change (January 1, 2019, for CCI; July 1, 2019, for TBCC). Clinical outcomes and parameters for mobilization and engraftment were assessed. Although not predefined as formal outcomes of the study, percent uptake (an indicator of the extent of change in product used from the originator to the biosimilar) and drug expenditure savings were also calculated.

\section{METHODS}

This study was a retrospective pre-post data review for patients who underwent autologous stem cell mobilization and transplant at the CCI and the TBCC, which provide a range of health care services for Albertans with cancer. ${ }^{15}$ At these 2 facilities combined, more than 200 patients undergo ASCT annually. Patient care is managed by the Northern Alberta Blood and Marrow Transplant Program (in Edmonton) and the Alberta Blood and Marrow Transplant Program (in Calgary), involving treatment management provided by hematology physicians, nurses, pharmacists, and various support staff. Data for all patients are prospectively collected within the transplant programs as part of quality assurance programs, with patient consent provided for research and regulatory body review. 
The study used data from consecutive patients treated at each centre with originator filgrastim in the 6 months before the defined date of product change or the biosimilar product in the 6 months afterward. The time frame of 12 months total was determined as being suitable to collect data for 100 patients at each centre, based on historical average annual numbers of ASCT patients at each site. Quality management consultants at each site collect and manage the data for their respective sites, and the separate data sets were combined for the purpose of this study. All data were anonymized, such that patient identity could not be discerned during the statistical analysis.

\section{Participants}

Consecutive patients with all categories of diagnosis who underwent stem cell mobilization were included in the data set. The overall study period was from July 1, 2018, to November 30, 2019.

The dosage of filgrastim prescribed for patients was based on standardized provincial dose banding according to patient weight categories; for each patient, the optimal dose of filgrastim was selected (5-10 $\mu \mathrm{g} / \mathrm{kg}$ daily) according to the patient's weight and risk factors. Advanced age, diagnosis of non-Hodgkin lymphoma, previous radiation therapy or extensive chemotherapy, previous treatment with lenalidomide, previous mobilization failure, low pre-apheresis circulating CD34+ cell counts, diabetes, and smoking are risk factors for poor mobilization or failure. ${ }^{16}$ Filgrastim was administered either alone or in combination with mobilizing chemotherapy agents. ${ }^{16}$ Patients received GCSF beginning on the day indicated in the protocol and continuing until completion of apheresis, typically for between 3 and 7 days of GCSF therapy. For mobilization by combined chemotherapy and GCSF, usual regimens had patients starting GCSF on about day 7 to 9 , with apheresis scheduled for days 12 to 14 , whereas mobilization involving salvage chemotherapy regimens had patients starting GCSF on day 14, with apheresis on days 19 to 21 . In cases with predicted poor mobilization based on risk factors, if optimal mobilization was not achieved with filgrastim with or without chemotherapy (total CD34+ cell counts $<20 \times 10^{6}$ cells/L after 4 days of GCSF) or there had been a prior failed attempt at mobilization with GCSF with or without chemotherapy, plerixafor was administered. Apheresis, directed by the CD34+ count, was performed with the Spectra Optia apheresis system (Terumo BCT). The minimum apheresis volume was $8 \mathrm{~L}$. All patients received the same level of care and follow-up from the respective transplant programs.

\section{Interventions}

The formulary product to be used for stem cell mobilization and collection was changed from originator filgrastim to the biosimilar in January 2019 (at the CCI) and July 2019 (at the TBCC), which defined the time point of comparison. After treatment with GCSF, the clinical effectiveness of stem cell mobilization was determined using data routinely collected by the blood and marrow programs. The primary effectiveness parameters were time from mobilization to collection, CD34+ cells collected, time to neutrophil engraftment, time to platelet engraftment, average length of stay, and success of mobilization. A harvest of CD34+ cells equal to or greater than $2 \times 10^{6}$ cells/kg body weight per transplant was defined as successful collection. Neutrophil engraftment was defined as an absolute neutrophil count of $0.5 \times 10^{9} / \mathrm{L}$, and platelet engraftment was defined as a platelet count of $20 \times 10^{9} / \mathrm{L}$. Time to neutrophil and platelet engraftment was defined by the first date of 3 and 7 consecutive values, respectively, over the threshold value. Secondary outcomes were use of plerixafor, GCSF dose, duration of GCSF therapy, processing volume, number of collections, and survival status. Baseline characteristics were included for comparison of patient age at time of transplant, sex, cancer diagnosis, and chemotherapy protocol (mobilization with GCSF and chemotherapy combined or with GCSF alone).

\section{Statistical Analysis}

Descriptive statistics were used to report the study variables. Means and standard deviations were calculated for normally distributed continuous variables, medians and ranges for non-normally distributed continuous variables, and frequencies and proportions for categorical variables. The correlation between 2 categorical variables was determined using $\chi^{2}$ tests, and means were compared between the 2 study arms using independent $t$ tests. A $p$ value less than 0.05 and 95\% confidence intervals (CIs) for the difference between means were used for determining statistical significance. Two-sided tests were used for the analysis, which was performed with SPSS software, version 25 (IBM Corporation). Patients with incomplete data for any of the variables were excluded from the final statistical analysis for that parameter. The impact on drug expenditures was estimated on the basis of a $17 \%$ per unit savings of the biosimilar compared with the originator (according to product pricing on the Alberta Drug Benefit List: $\$ 173.19$ for $300 \mu \mathrm{g}$ of the originator product and $\$ 144.31$ for $300 \mu \mathrm{g}$ of the biosimilar product), an estimated 200 patients undergoing ASCT annually, and an average dosage of $650 \mu \mathrm{g}$ daily for 5.4 days (according to values calculated in this study).

\section{Ethical Considerations}

The ethical aspects of implementing and studying the interventions in this study were guided by A Project Ethics Community Consensus Initiative (ARECCI) Ethics Guideline Tool. ${ }^{17}$ The ARECCI screening tool ${ }^{18}$ was used to assess the ethical risk of this quality improvement project, which was assessed as "somewhat more than minimal risk". Thus, the "second opinion review" process was completed, which classified the project as a health care improvement project 
and therefore determined that the protocol did not require review through the Health Research Ethics Board (HREB) Cancer Committee. ${ }^{19}$

\section{RESULTS}

Overall, the study included data from 102 consecutive patients treated with originator filgrastim and 101 patients treated with the biosimilar product, all of whom underwent stem cell mobilization according to institutional guidelines. Of the 203 patients, 105 were treated at the CCI and 98 at the TBCC.

Baseline patient characteristics (Tables 1 and 2) were similar, with almost equal numbers of patients treated with originator filgrastim $(n=102)$ and the biosimilar $(n=101)$. The median age of patients at the time of transplant was 59 years, and $63.1 \%(128 / 203)$ were male. The proportions of male and female patients using each product were similar. The most common diagnosis was multiple myeloma $(106 / 203$ [52.2\%]) and the least common was germ cell disease $(5 / 203[2.5 \%])$. A greater proportion of patients with multiple myeloma were treated with the biosimilar product than with the originator (55/101 [54.5\%] versus 51/102 [50.0\%]), whereas more of the patients with lymphoma were treated with the originator product than with the biosimilar (44/102 [43.1\%] versus 38/101 [37.6\%]). Survival was similar between groups: $94.1 \%(96 / 102)$ in the originator group versus $96 \%$ (97/101) in the biosimilar group.

The results indicated similar effectiveness for the originator filgrastim and biosimilar products when used for stem cell mobilization before ASCT. Combined results are reported in Table 1 and Table 2. In addition, site-specific results for all parameters were analyzed for the CCI and the TBCC individually; no significant differences in results were observed between the 2 centres (data not shown). The primary effectiveness parameters are reported in Figure 1 , Table 1 , and Table 2 . There were no statistically significant differences between the originator and the biosimilar in the time from mobilization to collection (difference of means -0.9 days, $95 \%$ CI -2.12 to $0.32, p=0.13$ ), time for neutrophil engraftment (difference of means 0 days, $95 \%$ CI -0.36 to $0.36, p=0.82$ ), time for platelet engraftment (difference of means 1 day, $95 \% \mathrm{CI}-0.55$ to $2.55, p=0.22$ ), or average length of stay (difference of means -0.7 day, $95 \% \mathrm{CI}-2.71$ to $1.31, p=0.46$ ). The average CD34+ collection was $7.2 \times 10^{6}$ cells $/ \mathrm{kg}$ body weight for originator filgrastim and $8.2 \times 10^{6}$ cells $/ \mathrm{kg}$ body weight for the biosimilar (difference of means $-1 \times 10^{6}$ cells $/ \mathrm{kg}$ body weight, $95 \% \mathrm{CI}-2.11$ to $0.11, p=0.06$ ). Both values surpassed what is considered a successful harvest. The mean number of collections was 1.4 in both groups $(p=0.65)$. Successful harvest of stem cells was achieved in $98 \%$ of the patients, with mobilization failure for 2 patients in each group.

Overall, $26.0 \%$ of the patients required use of plerixafor, $23.5 \%$ in the biosimilar group and $28.4 \%$ in the originator group $(p=0.42)$. Data on plerixafor use were missing for 3 patients (about 2\%). The average daily GCSF dose was $634.7 \mu \mathrm{g}$ in the originator group and $662.8 \mu \mathrm{g}$ for the biosimilar (difference of means $-28.1 \mu \mathrm{g}, 95 \% \mathrm{CI}-86.21$ to $30.01, p=0.34$ ). The dosage of GCSF has been standardized within the organization according to the number of transplants and other previously defined risk factors for failed

TABLE 1. Baseline Characteristics of Patients and Induction Therapy

\begin{tabular}{|c|c|c|c|c|c|c|}
\hline \multirow[b]{2}{*}{ Characteristic } & \multicolumn{6}{|c|}{ No. (\%) of Patients ${ }^{a}$} \\
\hline & \multicolumn{2}{|c|}{$\begin{array}{c}\text { Overall } \\
(n=203)\end{array}$} & \multicolumn{2}{|c|}{$\begin{array}{l}\text { Originator } \\
(n=102)\end{array}$} & \multicolumn{2}{|c|}{$\begin{array}{c}\text { Biosimilar } \\
(n=101)\end{array}$} \\
\hline \multicolumn{7}{|l|}{ Age at transplant (years) } \\
\hline Mean \pm SD & \multicolumn{2}{|c|}{$55.8 \pm 12.4$} & \multicolumn{2}{|c|}{$55.6 \pm 12.4$} & \multicolumn{2}{|c|}{$55.9 \pm 12.5$} \\
\hline Median (range) & \multicolumn{2}{|c|}{$59(18-78)$} & \multicolumn{2}{|c|}{$59(24-78)$} & \multicolumn{2}{|c|}{$59(18-72)$} \\
\hline \multicolumn{7}{|l|}{ Sex } \\
\hline Male & 128 & $(63.1)$ & 69 & $(67.6)$ & 59 & $(58.4)$ \\
\hline Female & 75 & $(36.9)$ & 33 & $(32.4)$ & 42 & $(41.6)$ \\
\hline \multicolumn{7}{|l|}{ Diagnosis } \\
\hline Autoimmune condition (Fabry disease, scleroderma, multiple sclerosis) & 10 & $(4.9)$ & 5 & $(4.9)$ & 5 & $(5.0)$ \\
\hline Lymphoma (Hodgkin and non-Hodgkin disease) & 82 & $(40.4)$ & 44 & $(43.1)$ & 38 & (37.6) \\
\hline Multiple myeloma & 106 & $(52.2)$ & 51 & $(50.0)$ & 55 & (54.5) \\
\hline Germ cell disease & 5 & $(2.5)$ & 2 & $(2.0)$ & 3 & $(3.0)$ \\
\hline \multicolumn{7}{|l|}{ Mobilization with GCSF alone } \\
\hline Yes & 14 & $(6.9)$ & 8 & $(7.8)$ & 6 & (5.9) \\
\hline No & 189 & (93.1) & 94 & $(92.2)$ & 95 & (94.1) \\
\hline
\end{tabular}

GCSF = granulocyte colony-stimulating factor, SD = standard deviation .

aExcept where indicated otherwise. 
TABLE 2. Comparison of Originator Filgrastim and Biosimilar Product

\begin{tabular}{|c|c|c|c|c|c|c|c|}
\hline \multirow[b]{2}{*}{ Variable } & \multicolumn{4}{|c|}{ Group; Mean \pm SD } & \multirow[b]{2}{*}{$\begin{array}{c}p \\
\text { Value }^{b}\end{array}$} & \multirow{2}{*}{\multicolumn{2}{|c|}{$\begin{array}{l}\text { Difference of Means } \\
\qquad(95 \% \mathrm{Cl})\end{array}$}} \\
\hline & \multicolumn{2}{|c|}{$\begin{array}{c}\text { Originator } \\
(n=102)\end{array}$} & \multicolumn{2}{|c|}{$\begin{array}{c}\text { Biosimilar } \\
(n=101)\end{array}$} & & & \\
\hline Age at transplant (years) & \multicolumn{2}{|c|}{$55.6 \pm 12.4$} & \multicolumn{2}{|c|}{$55.9 \pm 12.4$} & 0.84 & -0.3 & $(-3.73$ to 3.13$)$ \\
\hline Time from mobilization to collection (days) & \multicolumn{2}{|c|}{$11.2 \pm 4.4$} & \multicolumn{2}{|c|}{$12.1 \pm 4.4$} & 0.13 & -0.9 & $(-2.12$ to 0.32$)$ \\
\hline CD34+ cells collected ( $\times 10^{6} / \mathrm{kg}$ body weight) & \multicolumn{2}{|c|}{$7.2 \pm 3.4$} & \multicolumn{2}{|c|}{$8.2 \pm 4.5$} & 0.06 & -1 & $(-2.11$ to 0.11$)$ \\
\hline Time to neutrophil engraftment (days) & \multicolumn{2}{|c|}{$11.7 \pm 1.3$} & \multicolumn{2}{|c|}{$11.7 \pm 1.3$} & 0.82 & 0 & $(-0.36$ to 0.36$)$ \\
\hline Time to platelet engraftment (days) & \multicolumn{2}{|c|}{$17.8 \pm 6.7$} & \multicolumn{2}{|c|}{$16.8 \pm 4.2$} & 0.22 & 1 & $(-0.55$ to 2.55$)$ \\
\hline \multicolumn{8}{|l|}{ GCSF } \\
\hline Dose ( $\mu \mathrm{g} /$ day) & \multirow{2}{*}{\multicolumn{2}{|c|}{$\begin{array}{c}634.7 \pm 204.1 \\
5.4 \pm 2.4\end{array}$}} & \multirow{2}{*}{\multicolumn{2}{|c|}{$\begin{array}{c}662.8 \pm 215.1 \\
5.4 \pm 2.7\end{array}$}} & 0.34 & -28.1 & $(-86.21$ to 30.01$)$ \\
\hline Duration of delivery (days) & & & & & 0.89 & 0 & $(-0.71$ to 0.71$)$ \\
\hline Processing volume (L) & \multicolumn{2}{|c|}{$26.9 \pm 15.8$} & \multicolumn{2}{|c|}{$23.8 \pm 15.3$} & 0.16 & 3.1 & $(-1.21$ to 7.41$)$ \\
\hline Length of stay (days) & \multicolumn{2}{|c|}{$20.4 \pm 5.9$} & \multicolumn{2}{|c|}{$21.1 \pm 8.4$} & 0.46 & -0.7 & $(-2.71$ to 1.31$)$ \\
\hline No. of collections & \multicolumn{2}{|c|}{$1.4 \pm 0.6$} & \multicolumn{2}{|c|}{$1.4 \pm 0.5$} & 0.65 & & $(-0.15$ to 0.15$)$ \\
\hline \multicolumn{8}{|l|}{ Failed mobilization, no. (\%) } \\
\hline Yes & 2 & $(2.0)$ & 2 & $(2.0)$ & 0.86 & & NA \\
\hline No & 100 & $(98.0)$ & 99 & $(98.0)$ & & & \\
\hline \multicolumn{8}{|l|}{ Plerixafor administered, no. (\%)d } \\
\hline Yes & & $(28.4)$ & 23 & $(23.5)$ & 0.42 & & NA \\
\hline No & 73 & $(71.6)$ & 75 & $(76.5)$ & & & NA \\
\hline \multicolumn{8}{|l|}{ Survival status, no. (\%) } \\
\hline Alive & 96 & $(94.1)$ & 97 & $(96.0)$ & 0.53 & & NA \\
\hline Deceased & 6 & $(5.9)$ & 4 & $(4.0)$ & & & NA \\
\hline
\end{tabular}

$\mathrm{Cl}=$ confidence interval, $\mathrm{GCSF}=$ granulocyte colony-stimulating factor, $\mathrm{NA}=$ not applicable, $\mathrm{SD}=$ standard deviation.

${ }^{a}$ Except where indicated otherwise.

bIndependent $t$ test.

cOriginator minus biosimilar.

${ }^{\mathrm{d}}$ For the biosimilar group, data were missing for 3 patients, so percentages were calculated with a denominator of 98 .

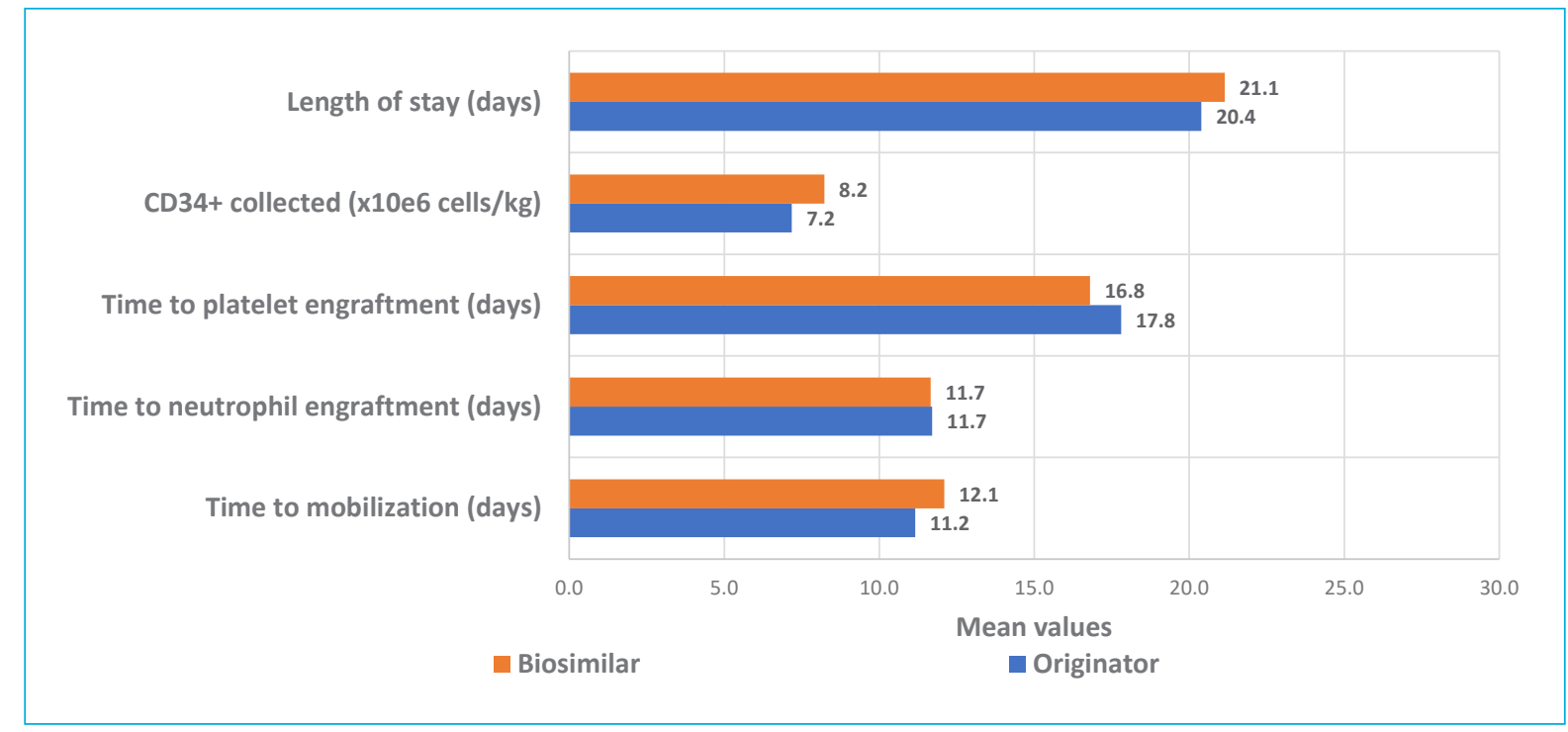

FIGURE 1. Comparison of originator and biosimilar filgrastim for primary effectiveness parameters. CD34+ counts are reported as number of cells $\times 10^{6} / \mathrm{kg}$ body weight. 
mobilization, ${ }^{16}$ starting with weight-based banding $(<60$ $\mathrm{kg}, 300 \mu \mathrm{g}$ daily; 60 to $90 \mathrm{~kg}, 480 \mu \mathrm{g}$ daily; and $>90 \mathrm{~kg}, 600$ $\mu \mathrm{g}$ daily), with adjustment for risks. The mean duration of GCSF therapy was 5.4 days for both groups, and processing volume was also similar between originator and biosimilar (difference of means 3.1 L, 95\% CI -1.21 to 7.41, $p=0.16$ ).

At each of the 2 study sites, the rate of conversion to use of the biosimilar after the defined date for switching products was $98 \%$, with an estimated $17 \%$ saving on the cost of the drug alone, amounting to $\$ 67500$ in annual drug costs for this indication. There were 3 patients who continued to receive the originator product after the defined date of switching to a biosimilar. These patients were either treated during the product transition period at the site or were given the originator product for reasons that were not clearly specified but likely attributable to order error. These patients were not included in our analysis.

\section{DISCUSSION}

Overall, this study demonstrated similarity of effectiveness between the originator filgrastim and biosimilar product for stem cell mobilization, providing real-world data to address prescribers' concerns about using the biosimilar. In particular, CD34+ cell collection was higher, although not significantly so, with biosimilar filgrastim than with originator filgrastim. This result is similar to that of a prospective non-inferiority study, ${ }^{12}$ which found a nonsignificant trend toward increased mobilization in the biosimilar arm. These results should be confirmed in future studies. The clinical importance of this difference may depend on individual patient acuity, since both values in our study exceeded the minimum of $2 \times 10^{6}$ cells $/ \mathrm{kg}$ body weight that is considered to represent a successful harvest. Other descriptive measures showed similarity between the groups of patients treated with the originator product and the biosimilar, confirming no differences in baseline characteristics. There was also no difference in the use of plerixafor, an agent used in circumstances of suboptimal collection or mobilization failure with filgrastim.

Prescribers' hesitancy in using biosimilars, due to a lack of confidence in biosimilars in general ${ }^{6,8}$ and specifically in the context of stem cell mobilization, ${ }^{7}$ is a barrier that has been discussed in the literature. Such hesitancy has been observed in the study organization to date, with poor uptake of 2 other biosimilar products, for nonhematological conditions, that have been added to the organization's acute care formulary. ${ }^{20}$ However, there are some important differences between these other biosimilars and filgrastim, such as their indications for use in chronic conditions and differences in program support offered by manufacturers, which have negatively affected uptake. As such, it may be difficult to directly compare all biosimilars available on the organization's formulary. Factors that may have improved uptake of the biosimilar filgrastim include 2 provincially coordinated bone marrow transplant programs and consensus of prescribers in their use of filgrastim for patients undergoing ASCT.

The filgrastim biosimilar is the first biosimilar to be evaluated in this organization using patient-specific parameters of effectiveness. Assessing these parameters in patients treated with originator versus biosimilar filgrastim products provides additional data to confirm the equivalency of the biosimilar in terms of effectiveness. Such data are missing from the Health Canada approval process for biosimilars; instead, that process allows extrapolation of results. ${ }^{2}$ Confirming equivalency of the biosimilar helps to support prescribing decisions, as well as guiding future decisions about the formulary status of each product. Information gained in this type of study may also be applied to future biosimilar products being considered for addition to the AHS provincial drug formulary.

Improved uptake of biosimilars is consequential to the sustainability of the health care system, given the substantial potential of these agents to reduce the costs associated with the biologics class of drugs. ${ }^{3,21-23}$ The list price of biosimilar filgrastim is approximately $17 \%$ lower than that of the originator product, which represents an opportunity for savings if it were to be used for all formulary indications. Filgrastim was 1 of the top 10 drugs by expenditure in the AHS in the 2017/18 and 2018/19 fiscal years (internal data), which could translate into significant savings with robust uptake. However, although biosimilar filgrastim was listed on the AHS provincial drug formulary for a different indication (neutropenia) in December 2017, a follow-up utilization audit found less than $30 \%$ uptake of the biosimilar after 12 months, a value that increased to approximately $63 \%$ by 18 months. The achievement of $98 \%$ uptake for the indication of autologous stem cell mobilization stands in stark contrast, and perhaps speaks to the value of health care improvement initiatives and coordinated program efforts within AHS to capitalize on organizational drug budget savings. Given that prescriber resistance was one of the barriers to use of biosimilars raised in a previous publication, ${ }^{7}$ the results of this study could help support clinical practice, improve use of biosimilars within the organization, reduce drug expenditures, and increase patients' access to high-cost medications. Additionally, using the biosimilar product is in line with government-funded outpatient drug plans and criteria for reimbursing biosimilar products as the first choice before the originator product. ${ }^{24}$ Alignment between acute care and ambulatory drug formularies is important to support continuity of care for patients and to promote system-wide health care savings.

\section{Limitations}

The main limitations of this study pertain to its observational design and small patient numbers. A retrospective study design cannot remove sources of bias or establish causality between exposure and outcome. ${ }^{25}$ Our data were limited to what was 
available through the electronic databases of the Northern Alberta Blood and Marrow Transplant Program and the Alberta Blood and Marrow Transplant Program. Additionally, the assessment of safety parameters was limited because the chart review did not include extraction of information about the adverse effects of each filgrastim product used; however, data on adverse effects are now being collected by both transplant programs and may be reported in a future publication. Because the study was focused on 2 oncology acute care facilities within the same organization, the findings may not be generalizable to other hospitals in the same province or to other health care organizations in Canada or internationally. Despite these limitations, use of an observational study design in this circumstance allowed for expedient and cost-effective use of existing staff resources to investigate real-world data to answer a clinical question. The limited number of patients and the short time frame for the study prevented use of a non-inferiority or prospective randomized study design, but may be considered for future research.

\section{CONCLUSION}

A coordinated change to using the biosimilar filgrastim product on our drug formulary was supported by a follow-up health care improvement study, confirming similarity of effectiveness between the originator product and the biosimilar in patients who underwent ASCT at 2 sites. This study provides valuable information to support prescribing decisions, as well as future decisions regarding the formulary status of both products. What was learned in this study can also be applied to future consideration of other biosimilar products for addition to the acute care formulary to increase cost savings, improve the sustainability of the health care system, and improve prescriber confidence in biosimilar drug products.

\section{References}

1. Drug product database [database on internet]. Health Canada; 2019 [cited 2019 Sep 19]. Available from: https://health-products.canada. ca/dpd-bdpp/index-eng.jsp

2. Biosimilar drugs. Canadian Agency for Drugs and Technologies in Health; 2019 Sep [cited 2019 Oct 3]. Available from: https://cadth.ca/ sites/default/files/pdf/biosimilar_drugs_professional_en.pdf

3. Fact sheet: biosimilars. Health Canada; 2019 Aug 27 [cited 2019 Oct 3] Available from: https://www.canada.ca/en/health-canada/services/drugs -health-products/biologics-radiopharmaceuticals-genetic-therapies/ applications-submissions/guidance-documents/fact-sheet-biosimilars .html

4. Griffith N, McBride A, Stevenson JG, Green L. Formulary selection criteria for biosimilars: considerations for US health-system pharmacists. Hosp Pharm. 2014;49(9):813-25.

5. Russell AS, Ahluwalla V, Barnabe C, Jamal S, Offer RC, Olsznski WP, et al. Subsequent entry biologics/biosimilars: a viewpoint from Canada. Clin Rheumatol. 2012;31(9):1289-92.

6. Dylst P, Vulto A, Simoens S. Barriers to the uptake of biosimilars and possible solutions: a Belgian case study. Pharmacoeconomics. 2014; 32(7):681-91.

7. Agboola F, Reddy P. Conversion from filgrastim to Tbo-filgrastim: experience of a large health care system. J Manag Care Spec Pharm. 2017;23(12):1214-8.

8. Lisenko K, Baertsch MA, Meiser R, Pavel P, Bruckner T, Kriegsmann $\mathrm{M}$, et al. Comparison of biosimilar filgrastim, originator filgrastim, and lenograstim for autologous stem cell mobilization in patients with multiple myeloma. Transfusion. 2017;57(10):2359-65.

9. Schmitt M, Hoffmann JM, Lorenz K, Publicover A, Schmitt A, Nagler A. Mobilization of autologous and allogeneic peripheral blood stem cells for transplantation in haematological malignancies using biosimilar G-CSF. Vox Sang. 2016;111(2):178-86.

10. Marchesi F, Mengarelli A. Biosimilar filgrastim in autologous peripheral blood hematopoetic stem cell mobilization and post-transplant hematologic recovery. Curr Med Chem. 2016;23:1-14.

11. Nichol C, Henry C, Couturier MA, Delépine P, Tripogney C, Buors C, et al. Biosimilars of filgrastim in autologous stem cell transplantation: certain differences for myeloma patients only [letter]. Leuk Lymphoma. 2017;58(9):2258-60.

12. Bhamidipati PK, Fiala MA, Grossman BJ, DiPersio JF, StockerlGolstein K, Gao F, et al. Results of a prospective randomized, openlabel, noninferiority study of tbo-filgrastim (Granix) versus filgrastim (Neupogen) in combination with plerixafor for autologous stem cell mobilization in patients with multiple myeloma and non-Hodgkin lymphoma. Biol Blood Marrow Transplant. 2017;23(12):2065-9.

13. Stakiw J, Sabry W, Elemary M, Bosch MJ, Danyluk P, Aggarwal V, et al. Biosimilar G-CSF versus originator G-CSF for autologous peripheral blood stem cell mobilization: a comparative analysis of mobilization and engraftment [abstract]. In: Proceedings of the ASH Annual Meeting; 2018 Dec 2; San Diego. Blood. 2018;132(Suppl):3345.

14. Health Products and Food Branch, Biologics and Genetic Therapies Directorate, Office of Policy and International Collaboration. How we monitor the safety of biosimilars after they have been authorized. In: Biosimilarbiologic drugs in Canada: fact sheet. Health Canada;2019 [cited 2019 Dec 26]. Available from: https://www.canada.ca/en/health-canada/ services/drugs-health-products/biologics-radiopharmaceuticals -genetic-therapies/applications-submissions/guidance-documents/fact -sheet-biosimilars.html\#a10

15. Hospitals \& facilities. In: Alberta Health Services homepage. Alberta Health Services; 2019 [cited 2019 Oct 1]. Available from: https://www .albertahealthservices.ca

16. Giralt S, Costa L, Schriber J, DiPersio J, Maziarz R, McCarty J, et al. Optimizing autologous stem cell mobilization strategies to improve patient outcomes: consensus guidelines and recommendations. Biol Blood Marrow Transplant. 2014;20(3):295-308.

17. A project ethics community consensus initiative (ARECCI) ethics guideline tool. Alberta Innovates; 2017 [cited 2018 Oct 4]. Available from: https://albertainnovates.ca/wp-content/uploads/2017/11/ARECCI -Ethics-Guideline-Tool.pdf

18. ARECCI ethics screening tool. Alberta Innovates; 2017 [cited 2018 Oct 4]. Available from: http://www.aihealthsolutions.ca/arecci/screening/ 453887/86cba73253e7f035499916d9e659e26c

19. Health Research Ethics Board of Alberta: Cancer Committee. HREBA; n.d. [cited 2018 Oct 4]. Available from: https://hreba.ca/hreba-cancer -committee/

20. Fenna J, Watkins K, Guirguis M. Biosimilar drugs and the hospital formulary: a Canadian experience. Can J Hosp Pharm. 2019;72(2):145-50.

21. Ventola CL. Evaluation of biosimilars for formulary inclusion: factors for consideration by P\&T committees. P T. 2015;40(10):680-9.

22. Jarrett $S$, Dingermann T. Biosimilars are here: a hospital pharmacist's guide to educating health care professionals on biosimilars. Hosp Pharm. 2015;50(10):884-93.

23. Ventola CL. Biosimilars part 2: potential concerns and challenges for P\&T committees. P T. 2013;38(6):329-35.

24. Government-sponsored biosimilar initiative. Alberta Blue Cross; 2019 [cited 2019 Dec 24]. Available from: https://www.ab.bluecross.ca/ government-plan/biosimilar-initiative.php

25. Boyko EJ. Observational research opportunities and limitations. J Diabetes Complications. 2013;27(6):642-8. 
Jennifer Fenna, BScPharm, MHS, is a Drug Utilization and Stewardship Pharmacist with Pharmacy Services, Alberta Health Services, Edmonton, Alberta.

Micheal Guirguis, BScPharm, PhD, is a Drug Stewardship Pharmacist with Pharmacy Services, Alberta Health Services, and is an Academic Adjunct Colleague with the Faculty of Pharmacy and Pharmaceutical Sciences, University of Alberta, Edmonton, Alberta.

Caroline Ibrahim, BSc, BPharm, MHS, is a Drug Utilization and Stewardship Pharmacist with Pharmacy Services, Alberta Health Services, Edmonton, Alberta.

Neeta Shirvaikar, BSc, MSc, MS, PhD, is a Quality Management Consultant with the Northern Alberta Blood and Marrow Transplant Program, Cross Cancer Institute, Edmonton, Alberta.

Irwindeep Sandhu, MD, is an Associate Professor with the Division of Clinical Hematology, Department of Medicine, University of Alberta, Edmonton, Alberta.
Sunita Ghosh, PhD (Biostatistics), PStat, PStat ${ }$ (ASA), is a Biostatistician with the Cross Cancer Institute, Alberta Health Services, Edmonton, Alberta.

Melissa Jenkins, BSc, is a Clinical Research Coordinator with the Alberta Blood and Marrow Transplant Program, Holy Cross Centre - Tom Baker Cancer Centre, Calgary, Alberta

Competing interests: None declared.

\section{Address correspondence to:}

Jennifer Fenna

Alberta Health Services

Suite 500, North Tower, Seventh Street Plaza

10030107 Street

Edmonton $A B$ T5J 3E4

email: jenny.fenna@ahs.ca

Funding: None received.

\section{BEST...is better}

\section{One resource for all types of compounding by pharmacies}

\section{WHAT'S INSIDE?}

- Information for pharmacists, pharmacy technicians, planners, architects, engineers-and others who are involved in decisions or activities that affect compounding

- Guidelines for aseptic compounding, non-aseptic compounding, and compounding which involves hazardous drugs-including radiopharmaceuticals

- Best and leading guidelines on topics such as training, planning and designing the physical environment, developing an air quality strategy, cleaning and decontaminating areas, monitoring the environment, garbing and hand hygiene, developing compounding procedures, documenting, and much more-all in only 230 pages

\section{(}

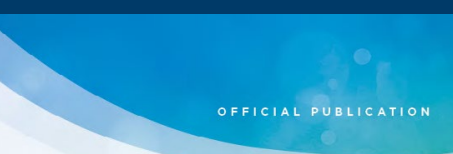

Compounding: Guidelines for Pharmacies

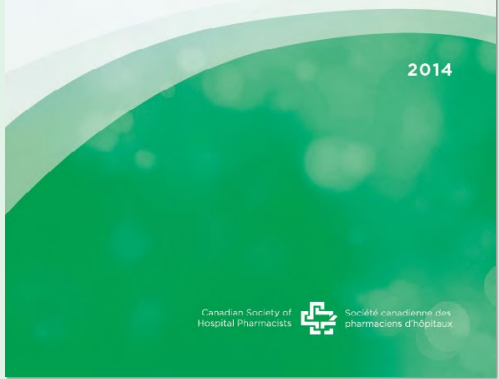

Learn what best looks like: add this publication to your library!
HAVE A SNEAK PEEK OR ORDER AT:

https://www.cshp.ca/compounding-guidelines-pharmacies CSHP MEMBERS PAY A DISCOUNTED PRICE
Canadian Society of Hospital Pharmacists
Société canadienne des pharmaciens d'hôpitaux 